\title{
Role of Self Efficacy as a Moderator in the Relationship of Psychological Distress, Psychosocial Adjustment and Educational Adjustment among University Students
}

\author{
Samina Rashid ${ }^{1}$, Maryam Khurshid ${ }^{2}$, Hina Saeed ${ }^{3}$
}

\begin{abstract}
Psychological distress is a well-known term that has serious effect on the individual's psychological and physical health. Now-a-days, it has become a topic of great concern for the psychosocial and educational adjustment amongst university students. The present study investigated the relationship between psychological distress, psychosocial adjustment and educational adjustment among university students. It also explored the moderating impact of selfefficacy on these variables. Data were collected from 304 university students (male=151, female=153). Kessler k10 Scale, General Self-efficacy Scale, Brief Adjustment Scale, Academic Adjustment Scale and Social Adjustment Scale were used to measure the study variables. Results of the current study revealed the inverse relationship between psychological distress, psychosocial and educational adjustment. Findings of regression analysis revealed that self-efficacy moderated the relationship between psychological distress, psychosocial adjustment and educational adjustment. Moreover, female students experienced more psychological distress as compared to male students. Results were discussed and limitations, suggestions and implications were presented for future research.
\end{abstract}

Key Words: Academic Adjustment, Psychological Distress, Psychological Adjustment, SelfEfficacy, Social Adjustment, University Students

Received: 02 December 2021; Revised Received: 24 December 2021; Accepted: 28 December 2021

${ }^{1}$ Assistant Professor, Department of Psychology, University of Wah, Wah Cantt, Pakistan.

${ }^{2}$ Lecturer, Department of Psychology (Female Section), International Islamic University, Islamabad, Pakistan.

${ }^{3}$ BS (Hons) Scholar, Department of Psychology, University of Wah, Wah Cantt, Pakistan.

\section{Corresponding Author Email:}

msmaryamkhurshid@gmail.com

\section{Introduction}

University student's life is connected with various stressors such as environmental transition, academic pressure, financial stressors, hurdles to goal achievement and many others. Due to all these stressors, students face plenty of negative emotions and they are at risk of low frustration tolerance that leads toward psychological distress. The global increase in the population of university students calls for the need to recognize the important factors that play role in their adjustment both educationally and psychosocially. Every transition phase in life comes with its own challenges and university life is one of them. According to Misra et al. (2003), all students have to face adjustment issues in the new environment either psychosocially or educationally. This has always been a nerve-wracking process ( $\mathrm{Li} \&$ Gasser 2005, Sumer et al., 2008).

Psychological distress can be defined as an emotional distress that might affect the daily living and social functioning of an individual (Wheaton, 2007). Psychological distress includes the student's reflection on the entire experience of university life which involve incidence inside and outside of the

This article is distributed under the terms of the Creative Commons Attribution Non Commercial 4.0 License (http://www.creativecommons.org/licenses/by-nc/4.0/) which permits nonCommercial use, reproduction and distribution of the work without further permission provided the original work is attributed as specified. 
classroom, the structure of course and educational interaction with staff and other students (Shea \& Christine, 2008). Globally, university students have to face psychological distress (Sharp \& Theiler, 2018). This distress increases the risk for developing other poor health behaviors and hinders the academic success. Evidence based research found high level of psychological distress among university students in, Middle East, Europe, Africa and Asia (Sharp \& Theiler, 2018). Research has been done in different countries like Western Nigeria (Adewuya et al., 2006), Japan (Tomoda et al., 2000), Turkey (Bayram \& Bilgel, 2008), all of which have identified the presence of psychological distress among students. Researches have suggested that higher level of psychological distress impacts the academic performance negatively. Eisenberg et al. (2007) revealed increased level of anxiety and depression is linked with impaired academic performance (Al Saadi et al., 2017).

Self-Efficacy helps students in managing psychological distress. Relevant literature found that students with high level of self efficacy have the ability to face more difficult task, increase capability to organize their time, show lower anxiety level, can cause different strategies of learning, have an ability to adjust with different academic settings and select difficult course of studies (Elmotaleb \& Sahalof, 2013). Findings of a study suggested that those who experience student life as a stressful phase is growing (Nedregard \& Olsen, 2014). Self-efficient students face difficulties and tasks as tests instead threat (Schwarzer, 1992). Therefore, for preventing academic stress and enhancing adjustment to the educational phase, selfefficacy is considered as an important source (del Mar Ferradás et al., 2018).

Within educational settings, self-efficacy becomes a censorious inspirational state as the student's psychosocial adjustment is poorly impacted by their psychological distress. Social functioning and adaptation specially cooperate in the student's educational accomplishments (Chen et al., 1997). Anderson et al. (2002), defined psychological adjustment as adaptation of an individual to the life changing occasions. The concept psychosocial represents the social and mental aspects in an individual's life, for example, age, job that concerns to an individual's life history and schooling (Pugh et al., 2002). Psychosocial maladjustment often causes malfunctioning that may be emotional, physical or cognitive in nature. Findings from a study revealed that student's educational achievements are indirectly or directly relying on the psychological adjustment (Valas, 2001) and students who are disruptive, socially withdrawal inhabited, shy and aggressive tends to perform poor in education as compared to those who are psychosocially adjusted (Dishion, 1990; Green et al., 1980).

Transition to university life may come with decline in psychosocial wellbeing. Stressors both related to academics and other life transitions like moving away from home, daily commute, all are related to it (Knifsend, 2018). This transition phase is a source of both personal growth and psychological maladjustment (Eisenberg et al., 2007). Feelings of being in between home and university impacts individual's wellbeing. Some students are not prepared for the challenges university life will throw at them and the demands it offers (Pleitz et al., 2015). A study revealed that social interaction with fellows and association with institution community might positively impact the student's educational experiences (Russell \& Petrie, 1992).

Educational adjustment relies on how well students fulfill educational requirements. Baker and Siryk (1999) defined educational adjustment as the degree of student's achievement in handling the different 
academic demands like inspiration, implementation, accomplishments and contentment within the academic domain. Educational setup with a satisfactory environment assists an individual in adaptation to the academic demands. Satisfaction of the students with faculty, campus's institution teaching method, behavior of classmates, time table, cocurricular activities \& rules and regulations impact his/her adjustment (Bhagat, 2017).

Students with higher self-efficacy have better ability to establish interpersonal relationships, better adaptation to the course, vocational projects and career outlook. Selfefficacy besides being an important factor in academic achievement also relates to the efforts, dedication to learn, self-regulation, less distress in tough situations and better adjustment to new learning environment (Van Rooij, 2018). Self-efficacy facilitates students to deal with difficult circumstances without crippling anxiety and perplexity. It helps students to enhance confidence about their abilities and necessary competency to handle academic obstacles. Consequently, they feel improved psychological adjustment (Yusoff, 2012). The higher the self-efficacy, higher will be the adaptation to university life (Kim et al., 2020).

Psychological distress has become a significant concern for the university students. Literature review from past 30 years has established that psychological distress is a persistent, deep-rooted and a long-lasting issue affecting students all over the world (Sharp \&Theiler, 2018). Present research was intended to explore the relationship between psychological distress, psychosocial adjustment, and educational adjustment among university students. This research also aimed to explore the moderating role of selfefficacy on the relationship between psychological distress, psychosocial adjustment, and educational adjustment. As the rationale of the study, there were less research work is present in Pakistan regarding the psychological distress faced by students and its detrimental consequences on their psychosocial and educational adjustment. When discussing about student's mental health and education, demographic variables also play an exceptional role. The research investigated the role of demographic variables including gender and family system of students to determine the impact they have on variables under study. Findings of this research will help understand the importance of self-efficacy in student's satisfaction and adjustment in the educational phase of their life. To achieve the objectives of this research, following hypotheses were formulated:

1. Self-efficacy, psychosocial and educational adjustment will be positively correlated.

2. Psychological distress, psychosocial and educational adjustment will be negatively correlated.

3. Self-efficacy would moderate the correlation between psychological distress, educational adjustment and psychosocial adjustment.

4. Students living in separate family system would face more psychological distress than students living in joint family system.

5. Female students would face more psychological distress than male students.

\section{Method}

\section{Research Design}

The research was a quantitative, correlational study using cross-sectional research design. Data was obtained from respondents through survey method using questionnaire.

\section{Sample}

A sample consisted of 304 university students $(N=304)$ including male and females $(n=151, n=153)$ with the age range from 19 to 30 years were selected from different universities of Pakistan including Taxila, Attock, Rawalpindi, Islamabad, Lahore, 
Karachi, Mianwali, Sargodha and Faisalabad. Participants were selected through random sampling technique. Education level of participants of the study included BS, MSc., BSc., BA., MPhil and PhD. Some of the data was gathered physically from universities of Taxila, Attock, Rawalpindi and Islamabad while rest of the data was gathered via online forms.

\section{Instruments}

\section{Kessler k10 Scale}

The scale was designed by Kessler and Mroczek (1992) and consists of statements about symptoms of anxiety and depression that an individual has undergone during past 4 weeks. Scale contains 10 items. Score assess on 5-point rating scale ranging from 1(none of the time) to 5(All of the time). High score shows high level of psychological distress.

\section{General Self-Efficacy Scale}

The scale by Schwarzer and Jerusalem (1995) comprises of 10 items that measure how people believe they can achieve their goals, despite difficulties. Score assess on 4point Likert type scale ranges from 1 (not at all) to 4 (exactly true). High scores reveal high level of self-efficacy.

\section{Academic Adjustment Scale}

The scale was developed by Baker and Siryk in 1989. Academic adjustment scale contains 25 items. The scale measures that how well a student is adjusted to the academic demands. Score assess on 4-point rating scale ranging from 1 (not at all true) to 4 (very true). High score shows high level of academic adjustment.

\section{Social Adjustment Scale}

The scale was developed by Baker and Siryk in 1984. The scale measures the student's adjustment to the educational environment. The scale contains 25 items. Score assess on 4-point rating scale ranging from 1 (not at all true) to 4 (very true). High score reveals high level of social adjustment.

\section{Brief Adjustment Scale}

The scale was developed by Cruz et al. (2019) to assess the general psychological adjustment among students. The scale contains 6 items. Scorer assess on 7-point rating scale ranging from 1 (not at all) to 7 (extremely). High scores show high level of psychological maladjustment.

\section{Procedure}

To conduct the present study, data was collected from the universities of Taxila, Attock, Rawalpindi, Islamabad, Lahore, Karachi, Mianwali, Sargodha and Faisalabad through online and physical means. Sample comprised of 304 university students including males and females. The sample was approached by using random sampling technique. Informed consent was obtained before proceeding with the questions.

\section{Ethical Considerations}

To gather the study data, formal approval from the Psychology Department of University of Wah was attained. Permission from the head of the universities was also taken. Moreover, participants of the study were ensured that the gathered information will be kept private and confidential and only used for study purposes. During data collection, every confusion regarding the research instruments were made clear. Moreover, participants were requested to be honest, and were acknowledged for their kind contribution.

\section{Data Analysis}

Data was analyzed by using Statistical Package for Social Sciences (SPSS) version 22. Pearson product moment correlation and Linear regression analysis was carried out to measure the relationship of psychological distress with psychosocial and educational adjustment and the moderating effect of self efficacy. 


\section{Result}

\section{Table 1}

Descriptive and Alpha Reliability for the Scales of Psychological Distress, Self-efficacy, Psychosocial Adjustment and Educational Adjustment $(N=304)$

\begin{tabular}{|c|c|c|c|c|c|c|c|c|}
\hline \multirow[t]{2}{*}{ Variables } & \multirow{2}{*}{$\begin{array}{l}\text { No } \\
\text { of } \\
\text { items }\end{array}$} & \multirow[t]{2}{*}{$M$} & \multirow[t]{2}{*}{$S D$} & \multirow[t]{2}{*}{$\alpha$} & \multirow[t]{2}{*}{ Skewness } & \multirow[t]{2}{*}{ Kurtosis } & \multicolumn{2}{|c|}{ Range } \\
\hline & & & & & & & Actual & Potential \\
\hline $\begin{array}{l}\text { Psychological } \\
\text { distress }\end{array}$ & 10 & 24.7 & 6.22 & .71 & .762 & 2.493 & $10-57$ & $10-50$ \\
\hline Self-efficacy & 10 & 29.01 & 5.65 & .81 & -5.63 & .238 & $11-40$ & $10-40$ \\
\hline $\begin{array}{l}\text { Psychological } \\
\text { adjustment }\end{array}$ & 6 & 18.02 & 7.54 & .80 & .905 & 1.040 & $6-42$ & $6-42$ \\
\hline $\begin{array}{l}\text { Social } \\
\text { adjustment }\end{array}$ & 25 & 75.13 & 9.91 & .82 & -.390 & -.076 & $46-99$ & $25-100$ \\
\hline $\begin{array}{l}\text { Academic } \\
\text { adjustment }\end{array}$ & 25 & 77.39 & 10.08 & .85 & -.861 & 2.133 & $\begin{array}{l}26- \\
100\end{array}$ & $25-100$ \\
\hline
\end{tabular}

Note, $N=193 ; \mathrm{k}=$ no of items, $\alpha=$ Cronbach Alpha, $M=$ mean, $S D=$ standard deviation.

Table 1 revealed descriptive and alpha from .71 to .85 . Cronbach's alpha for all coefficient for all the studied variables ranges scales revealed strong inter-item consistency.

Table 2

Pearson Product Correlation among Psychological Distress, Self-efficacy, Psychosocial Adjustment and Educational Adjustment $(N=304)$

\begin{tabular}{|c|c|c|c|c|c|c|}
\hline & Variable & 1 & 2 & 3 & 4 & 5 \\
\hline 1. & $\begin{array}{l}\text { Psychological } \\
\text { distress }\end{array}$ & $\ldots \ldots$ & $\cdots \cdots$ & $\cdots \cdots$ & $\ldots \ldots$ & $\ldots \ldots$ \\
\hline 2. & Self-efficacy & $-.33 * *$ & $\ldots \ldots$ & $\ldots \ldots \ldots$ & $\ldots \ldots \ldots$ & $\ldots \ldots$ \\
\hline 3. & $\begin{array}{l}\text { Psychological } \\
\text { adjustment }\end{array}$ & $.59 * *$ & $-.52 * *$ & $\ldots \ldots \ldots$ & $\ldots \ldots$ & \\
\hline 4. & $\begin{array}{l}\text { Social } \\
\text { adjustment }\end{array}$ & $-.42 * *$ & $.49 * *$ & $-.52 * *$ & & \\
\hline 5. & $\begin{array}{l}\text { Academic } \\
\text { adjustment }\end{array}$ & $-.44 * *$ & $.52 * *$ & $-.51 * *$ & $.70 * *$ & \\
\hline
\end{tabular}

$* * p<.01$

Table 2 indicated that there was significant negative relationship of psychological distress with self-efficacy, psychological adjustment (low scores of psychological adjustment scales indicate high level of psychological adjustment), social adjustment and educational adjustment. Furthermore, there is a significant and positive relationship of self-efficacy with psychological adjustment (low scores show better adjustment), social adjustment and educational adjustment. This shows that high psychological distress is linked with low level of self-efficacy, psychological adjustment, social adjustment, and educational adjustment. 
Table 3

Moderated Regression Analysis Predicting the Effect of Self-efficacy on the Relationship of Psychological Distress and Psychological Adjustment $(N=304)$

\begin{tabular}{|c|c|c|c|c|c|c|c|}
\hline 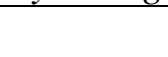 & \multirow[b]{2}{*}{ Predictors } & \multicolumn{6}{|c|}{ Outcome: Psychological Adjustment } \\
\hline & & $\boldsymbol{B}$ & $S E$ & $\mathbf{B}$ & $t$ & $\Delta R^{2}$ & $\boldsymbol{F}$ \\
\hline \multirow[t]{4}{*}{ Model 1} & & & & & & .471 & $133.89 * * *$ \\
\hline & (constant) & 2.11 & .04 & & .000 & & \\
\hline & $\begin{array}{l}\text { Psychological } \\
\text { Distress }\end{array}$ & $.46^{* *}$ & .04 & .46 & 10.45 & & \\
\hline & $\begin{array}{l}\text { Psychological } \\
\text { Adjustment }\end{array}$ & $-.77 * * *$ & .04 & -.37 & -8.30 & & \\
\hline \multirow[t]{7}{*}{ Model 2} & & & & & & .009 & $92.26 * * *$ \\
\hline & (constant) & $1.73 * *$ & .75 & & 2.28 & & \\
\hline & $\begin{array}{l}\text { Psychological } \\
\text { Distress }\end{array}$ & $.90 * * *$ & .19 & .90 & 4.59 & & \\
\hline & Self-Efficacy & -.01 & .16 & -.01 & -0.86 & & \\
\hline & Psychological & $-.00 * *$ & .001 & -.47 & -2.28 & & \\
\hline & Distress $\mathrm{x}$ Self & & & & & & \\
\hline & Efficacy & & & & & & \\
\hline
\end{tabular}

Table 3 shows the moderated multiple regression analysis showing the moderating effects of self-efficacy as moderator between psychological distress and psychological adjustment. The $R^{2}$ value of .48 revealed that the predictor explained $48 \%$ variance in the outcome variable with $F(3,300)=92.26 * * *$, $p<000$. The main effect of psychological distress $(B=.90, p<.000)$. The moderating effect of self-efficacy was significant by the predictor psychological distress $(B=-.002$, $p<.000)$.

\section{Table 4}

Regression Analysis Predicting the Moderating Effect of Self-efficacy on the Relationship of Psychological Distress and Social Adjustment $(N=304)$

\begin{tabular}{|c|c|c|c|c|c|c|c|}
\hline & \multirow[b]{2}{*}{ Predictors } & \multicolumn{5}{|c|}{ Outcome: Social Adjustment } & \multirow[b]{2}{*}{$\boldsymbol{F}$} \\
\hline & & $\boldsymbol{B}$ & $S E$ & B & $t$ & $\Delta R^{2}$ & \\
\hline \multirow[t]{4}{*}{ Model 1} & & & & & & .32 & $71.08 * * *$ \\
\hline & (constant) & -1.13 & .04 & & .000 & & \\
\hline & Psychological Distress & $-.28 * * *$ & .05 & -.28 & -5.64 & & \\
\hline & Social Adjustment & $.40 * * *$ & .05 & .40 & 7.97 & & \\
\hline \multirow[t]{5}{*}{ Model 2} & & & & & & .02 & $52.26 * * *$ \\
\hline & (constant) & $-2.72 * * *$ & .85 & & -3.19 & & \\
\hline & Psychological Distress & $-.97 * * *$ & .22 & -.97 & -4.40 & & \\
\hline & Self-Efficacy & -.15 & .18 & -.15 & -.86 & & \\
\hline & $\begin{array}{l}\text { Psychological Distress } \\
\text { x Self Efficacy }\end{array}$ & $.00 * * *$ & .001 & .74 & 3.20 & & \\
\hline
\end{tabular}

$* * * p<0.001$ 
Table 4 shows the moderated regression analysis sowing the moderating effects of self-efficacy as moderator between the psychological distress and social adjustment. The $R^{2}$ value of .343 revealed that the predictor explained $34.3 \%$ variance in the outcome variable with $F(3,300)=52.26 * * *$, $p<.000$. The main effect of psychological distress $(B=-.97, p<.000)$. The moderating effect of self-efficacy was significant by the predictor psychological distress $(B=.004$, $p<.000)$.

Table 5

Regression Analysis Predicting the Moderating Effect of Self-efficacy on the Relationship of Psychological Distress and Educational Adjustment $(N=304)$

\begin{tabular}{|c|c|c|c|c|c|c|c|}
\hline & \multirow[b]{2}{*}{ Predictors } & \multicolumn{6}{|c|}{ Outcome: Educational Adjustment } \\
\hline & & $\boldsymbol{B}$ & $S E$ & B & $t$ & $\Delta R^{2}$ & $\boldsymbol{F}$ \\
\hline \multirow[t]{4}{*}{ Model 1} & & & & & & .34 & $80.83 * * *$ \\
\hline & (constant) & -4.41 & .04 & & .000 & & \\
\hline & $\begin{array}{l}\text { Psychological } \\
\text { Distress }\end{array}$ & $-.29 * * *$ & .04 & -.29 & -6.05 & & \\
\hline & $\begin{array}{l}\text { Educational } \\
\text { Adjustment }\end{array}$ & $.41 * * *$ & .04 & .41 & 8.46 & & \\
\hline \multirow[t]{7}{*}{ Model 2} & & & & & & .06 & $69.58 * * *$ \\
\hline & (constant) & $-4.48 * * *$ & .80 & & -5.55 & & \\
\hline & $\begin{array}{l}\text { Psychological } \\
\text { Distress }\end{array}$ & $-1.43 * * *$ & .21 & -1.43 & -6.85 & & \\
\hline & Self-Efficacy & $-.50 * *$ & .17 & -.50 & -2.92 & & \\
\hline & Psychological & $.006 * * *$ & .001 & 1.22 & 5.56 & & \\
\hline & Distress $\mathrm{x}$ Self & & & & & & \\
\hline & Efficacy & & & & & & \\
\hline
\end{tabular}

Table 5 shows the moderated multiple regression analysis showing the moderating effect of self-efficacy as moderator between the psychological distress and educational adjustment. The $R^{2}$ value of .41 revealed that the predictor explained $41 \%$ variance in the outcome variable with $F(3,300)=69.58 * * *$, $p<.000$. The main effect of psychological distress $(B=1.43, p<.000)$. The moderating effect of self-efficacy was significant by the predictor psychological distress $(B=.006$, $p<.000)$.

Table 6

t test for Gender Difference in Psychological Distress among University Students $(N=304)$

\begin{tabular}{|c|c|c|c|c|c|c|c|c|c|}
\hline \multirow[b]{2}{*}{ Variable } & \multicolumn{2}{|c|}{$\begin{array}{l}\text { Male } \\
(n=151)\end{array}$} & \multicolumn{2}{|c|}{$\begin{array}{l}\text { Female } \\
(n=153)\end{array}$} & \multirow[b]{2}{*}{ i } & \multirow[b]{2}{*}{$p$} & \multicolumn{3}{|c|}{$95 \% \mathrm{CL}$} \\
\hline & $M$ & $S D$ & $M$ & $S D$ & & & $L L$ & $\boldsymbol{U L}$ & Cohen's d \\
\hline $\begin{array}{l}\text { Psychological } \\
\text { Distress }\end{array}$ & 24.15 & 6.73 & 26.05 & 5.69 & -1.21 & .04 & -1.91 & -1.09 & 0.30 \\
\hline
\end{tabular}

Table 6 indicates a significant difference for psychological distress between both groups. The females report high level of psychological distress $(M=26.05, S D=5.69)$ as compared to males. 
Table 7

$t$ test for Difference of Family Status on Psychological Distress among University Students $(N=304)$

\begin{tabular}{|c|c|c|c|c|c|c|c|c|c|}
\hline \multirow[b]{2}{*}{ Variable } & \multicolumn{2}{|c|}{$\begin{array}{r}\text { Separate } \\
(n=163)\end{array}$} & \multicolumn{2}{|c|}{$\begin{array}{c}\text { Joint } \\
(n=141)\end{array}$} & \multirow[b]{2}{*}{$t$} & \multirow[b]{2}{*}{$p$} & \multicolumn{3}{|c|}{$95 \% \mathrm{CL}$} \\
\hline & $M$ & $S D$ & $M$ & $S D$ & & & $L L$ & $U L$ & Cohen's d \\
\hline $\begin{array}{l}\text { Psychological } \\
\text { Distress }\end{array}$ & 24.93 & 6.09 & 24.72 & 6.46 & .17 & .47 & -1.32 & 1.58 & 0.02 \\
\hline
\end{tabular}

Table 7 indicates a nonsignificant $t$ value $(t=.17, p>0.05)$ for psychological distress between two groups. However, result revealed that students living in a separate family system report high level of

\section{Discussion}

There is a growing concern about the psychological well-being of students going through university phase. Psychological distress is a persistent issue affecting students globally. The transition brings with it a lot of challenges and poor coping results in maladjustment. Undoubtedly, higher the psychological distress experienced by students, higher will be the risk of academic failure and dropout (Ishii et al., 2018; Jaisoorya et al., 2017). The present study aimed to explore the relationship between psychological distress, psychosocial adjustment and educational adjustment. The moderating role of self-efficacy was also investigated. Furthermore, certain demographic variables were also explored including gender and family system to investigate their impact on the variables under study.

Firstly, it was hypothesized that self-efficacy has a positive relationship with psychosocial adjustment and educational adjustment. Results from correlation analysis confirmed strong relationship between these variables (Table 2). Results of present study are consistent with the findings of a study that suggested a strong link between self-efficacy and educational adjustment (Brady-Amoon $\&$ Fueters, 2011). Similarly, results of present psychological distress $(M=24.93 S D=6.09)$ as compared to those living in joint family system.

study are in line with that of Poyrazli (2001) which showed that students with higher academic self-efficacy report fewer adjustment problems. Moreover, students with higher self-efficacy showed better academic performance (Shkullaku, 2013).

Secondly, it was hypothesized that psychological distress has a negative relationship with psychosocial adjustment and educational adjustment. The results of the study confirmed the hypothesis (Table 2). The results can be traced back into the literature that suggested negative correlation between academic performance and psychological distress. The results of present study are consistent with the findings of Eisenberg et al. (2007) which documented that psychological distress results in impaired academic performance.

Present study hypothesized that self-efficacy would moderate the relationship between psychological distress, educational adjustment and psychosocial adjustment. Previous studies did not examine the moderating role of self-efficacy with these variables under study instead they have been directly correlated with self-efficacy. Moksness (2019) provided evidence from research that has proved self-efficacy to be the moderating factor between life satisfaction and life stressors. Negative life 
events impact the ability of students to deal with the pressures of academic life. A study documented that positive correlation between negative life events and level of drop-out intentions was depreciated for the students who had higher self-efficacy (Samuel \& Burger, 2020). Consistent with this finding, present research confirmed the moderating role of self-efficacy in relation to psychological distress, psychosocial adjustment and educational adjustment (Table 3,4 \& 5). In other words, when students face psychological distress but are self-efficacious, they can overcome psychological distress and can easily adjust both educationally and psychosocially.

To explore the role of demographic variables on the psychological well-being of university students, it was hypothesized that psychological distress would be higher among female students as compared to male students. Results of the present study are in accordance with the findings of Porru et al. (2021) that showed higher prevalence of psychological distress in female students as compared to male students (Table 6). Furthermore, female students reported higher mental illness as compared to male students (Stallman, 2010). Consistent with the findings of current study, it was observed that self-reported psychological distress was higher in female students as compared to male students (Knapstad, 2021). Furthermore, similar to the findings of Wang et al. (2020), results showed higher prevalence of psychological distress among female students (Table 6).

It was hypothesized that students living in nuclear family systems would face more psychological distress as compared to those living in joint family systems. The results of present study are not significant for relationship between family systems and psychological distress among students (Table 7). However, less psychological distress was noted in students belonging from joint family systems. It might be because joint family system provides strong social support, more chances of disclosure of emotions and intimacy. Participants belonging from joint family systems are more adjusted as compared to those from nuclear family systems (Muzaffar, 2017).

\section{Conclusion}

Findings of present study identified that self efficacy play an effective role in the student's educational and psychosocial adjustment within university setting and also help students to overcome psychological distress they face due to environmental transition, academic pressure. Furthermore, results found less psychological distress in students belonging to joint family systems. Results also revealed that female students experienced more psychological distress as compared to male students. Findings of current study have clear implications in determining the need to call for the attention towards the psychological wellbeing of students in Pakistan. Better psychological health of students will lead to better academic adjustment and performance. The study imply that attention must be given to ensure that students are best equipped to manage the stressors they face during university life.

\section{Implications}

Self-efficacious students are not hesitant in confronting and dealing with the hurdles imposed on them during their academic career and better adjust with them, therefore, universities must introduce programs to enhance student's self-efficacy. Findings of current study have clear implications in determining the need to call for the attention towards the psychological wellbeing of students in Pakistan. Better psychological health of students will lead to better academic adjustment and performance. The study imply that attention must be given to ensure that students are best equipped to manage the stressors they face during university life and better cope with them. 


\section{Limitations and Suggestions}

The research explored limited demographic variables; it is suggested to explore more demographics in future. Present study used cross-sectional method to study the variables. Future research should design longitudinal research and adopt mixed methods research approach. The current research comprised of sample of university students ranging from early to middle adulthood (19 to 30 years). It would be beneficial to study these constructs among school and college going students as major transitions beings through these phases.

\section{Conflict of Interest}

The authors declare no conflict of interest.

\section{Source of Funding}

The authors declare no funding.

\section{References}

Adewuya, A. O., Ola, B. A., \& Afolabi, O. O. (2006). Validity of the patient health questionnaire (PHQ-9) as a screening tool for depression amongst Nigerian university students. Journal of affective disorders, 96(1-2), 89-93.

Al Saadi, T., Zaher Addeen, S., Turk, T., Abbas, F., \& Alkhatib, M. (2017). Psychological distress among medical students in conflicts: a crosssectional study from Syria. Bio Medical Central Medical Education, 17(1), 173. https://doi.org/10.1186/s12909-0171012-2

Anderson, D. M., Keith, J., \& Novak, P. D. (2002). Mosby's medical dictionary $\left(6^{\text {th }} \mathrm{ed}\right)$. A harcourt health science company.

Baker, R. W., \& Siryk, B. (1984). Measuring adjustment to college. Journal of Counseling Psychology, 31(2), 179189. https://doi.org/10.1037/00220167.31.2.179
Baker, R. W., \& Siryk, B. (1989). Student Adaptation to College Questionnaire Manual. Los Angeles: Western Psychological Services.

Baker, R. W. \& Siryk, B. (1999). SACQ: Student Adaptation to College Questionnaire Manual. Los Angeles: Western Psychological Services.

Bayram, N., \& Bilgel, N. (2008). The prevalence and socio-demographic correlations of depression, anxiety and stress among a group of university students. Social psychiatry and psychiatric epidemiology, 43(8), 667-672.

Bhagat, P. (2017). Comparative study of adjustment among secondary school boys and girls. International Journal of Applied Research, 2(7), 91-95.

Brady-Amoon, P., \& Fuertes, J. N. (2011). Self-Efficacy, Self-Rated Abilities, Adjustment, and Academic Performance. Journal of Counseling \& Development, 89(4), 431438. doi:10.1002/j.1556-6676. 2011.tb02840.x

Chen, X., Rubin, K. H., \& Li, D. (1997). Relation between academic achievement and social adjustment: Evidence from Chinese children. Developmental Psychology, 33(3), 518- 525.

Cruz, R. A., Peterson, A. P., Fagan, C., Black, W., \& Cooper, L. (2019). Evaluation of the Brief Adjustment Scale-6 (BASE-6): A measure of general psychological adjustment for measurement-based care. Psychological Services. Advance online publication. http://dx.doi.org/10.1037/ser0000366 del Mar Ferradás, M., Freire, C., Rodríguez, S., \& Piñeiro, I. (2018). Selfhandicapping and self-esteem profiles and their relation to 
achievement goals. Annales of Psychology, 34(3), 545-554.

Dishion, T. J. (1990). The family ecology of boys' peer relations in middle childhood. Child development, 61(3), 874-892.

Eisenberg, D., Gollust, S. E., Golberstein, E., \& Hefner, J. L. (2007). Prevalence and correlates of depression, anxiety, and suicidality among university students. American journal of orthopsychiatry, 77(4), 534-542.

Elmotaleb, M.A. \& Saha1of, S.K. (2013). The role of academic self-efficacy as a mediator variable between perceived academic climate and academic performance. Journal Education and Learning, 2(3). doi:10.5539/jel.v2n3p117

Green, K. D., Forehand, R., Beck, S. J., \& Vosk, B. (1980). An assessment of the relationship among measures of children's social competence and children's academic achievement. Child development, 1149-1156.

Ishii, T., Tachikawa, H., Shiratori, Y., Hori, T., Aiba, M., Kuga, K., \& Arai, T. (2018). What kinds of factors affect the academic outcomes of university students with mental disorders? A retrospective study based on medical records. Asian journal of psychiatry, 32, 67-72.

Jaisoorya, T. S., Reddy, Y. J., Nair, B. S., Rani, A., Menon, P. G., Revamma, M., ... \& Thennarasu, K. (2017). Prevalence and correlates of obsessive-compulsive disorder and subthreshold obsessive-compulsive disorder among college students in Kerala, India. Indian journal of psychiatry, 59(1), 56.

Kessler, R., \& Mroczek, D. (1992). An update of the development of mental health screening scales for the us national health interview study [memo dated 12/22/92]. Ann Arbor(MI): Survey Research Center of the Institute for Social Research, University of Michigan.

Kim, J. S., Kim, J., \& Gelegjamts, D. (2020). Knowledge, attitude and self-efficacy towards palliative care among nurses in Mongolia: A cross-sectional descriptive study. Plos one, 15(7), e0236390.

Knapstad, M., Sivertsen, B., Knudsen, A. K., Smith, O. R. F., Aarø, L. E., Lønning, K. J., \& Skogen, J. C. (2021). Trends in self-reported psychological distress among college and university students from 2010 to 2018. Psychological medicine, 51(3), 470-478.

Knifsend, C. A. (2018). Intensity of activity involvement and psychosocial wellbeing among students. Active Learning in Higher Education, 146978741876032. doi:10.1177/146 9787418760324

Li, A., \& Gasser, M. B. (2005). Predicting Asian international students' sociocultural adjustment: A test of two mediation models. International Journal of Intercultural Relations, 29(5), 561-576.

Misra, R., Crist, M., \& Burant, C. J. (2003). Relationships among life stress, social support, academic stressors, and reactions to stressors of international students in the United States. International Journal of Stress Management, 10(2), 137.

Moksnes, U. K., Eilertsen, M. E. B., Ringdal, R., Bjørnsen, H. N., \& Rannestad, T. (2019). Life satisfaction in association with self-efficacy and stressor experience in adolescentsself-efficacy as a potential moderator. Scandinavian Journal of Caring Sciences, 33(1), 222-230. 
Muzaffar, N. N. (2017). Role of family system, positive emotions and resilience in social adjustment among Pakistani adolescents. Journal of Educational, Health and Community Psychology, 6(2), 46-58.

Nedregård, T., \& Olsen, R. (2014). Studentenes helse-og trivselsundersøkelse: SHoT 2010. Rapport. issn, 1504-7741.

Pleitz, J. D., MacDougall, A. E., Terry, R. A., Buckley, M. R., \& Campbell, N. J. (2015). Great Expectations: Examining the Discrepancy Between Expectations and Experiences on College Student Retention. Journal of College Student Retention: Research, Theory \& Practice, 17(1), $88-$

104. https://doi.org/10.1177/1521025 115571252

Porru, F., Robroek, S. J., Bültmann, U., Portoghese, I., Campagna, M., \& Burdorf, A. (2021). Mental health among university students: The associations of effort-reward imbalance and overcommitment with psychological distress. Journal of Affective Disorders, 282, 953-961.

Poyrazli, S. (2001). The role of assertiveness, academic experiences, and academic self-efficacy on psychosocial adjustment of graduate international students. University of Houston.

Pugh, K., Zhao, Y., Sheldon, S., \& Byers, J. (2002). Conditions for classroom technology innovations. Teachers' college record, 104(3), 482-515.

Russell, R. K., \& Petrie, T. A. (1992). Academic adjustment of college students: Assessment and counseling. In S. D. Brown \& R. W. Lent (Eds.), Handbook of counseling psychology, 485-511.

Samuel, R., \& Burger, K. (2020). Negative life events, self-efficacy, and social support: Risk and protective factors for school dropout intentions and dropout. Journal of Educational Psychology, 112(5), 973-986.

Schwarzer, R. (1992). Self-efficacy in the adoption and maintenance of health behaviors: Theoretical approaches and a new model. In R. Schwarzer (Ed.), Self-efficacy: Thought control of action (pp. 217-243). Hemisphere Publishing Corp.

Schwarzer, R., \& Jerusalem, M. (1995). Generalized Self Efficacy Scale. In J. Weinman, S. Wright, \& M. Johnton, Measures in health psychology: A user's portfolio. Causal and control beliefs (pp. 35-37). Windsor, UK: NFER-NELSON.

Sharp, J., \& Theiler, S. (2018). A review of psychological distress among university students: Pervasiveness, implications and potential points of interventions. International journal for The Advancement of counselling, 40(8), 193-212. Doi: 10.1007/s10447-018-9321-7

Shea, M., \& Christine, J. Y. (2008). Asian American student's cultural values, stigma, and self-Construal: Correlates of attitude towards professional help seeking. Journal of mental health Counselling, 30(2) 157-172. Doi: $10.17744 / \mathrm{m} 3 \mathrm{hc}$. 302.g662g5126r1352198.

Shkullaku, R. (2013). The relationship between self efficacy and academic performance in the Context of gender among Albanian students. European academic research, 1(4), 467-478.

Stallman, H. M. (2010). Psychological distress in university students: A comparison with general population data. Australian Psychologist, 45(4), 249-257.

Sümer, S., Poyrazli, S., \& Grahame, K. (2008). Predictors of depression and 
anxiety among international students. Journal of Counseling \& Development, 86(4), 429-437.

Tomoda, A., Mori, K., Kimura, M., Takahashi, T., \& Kitamura, T. (2000). One-year prevalence and incidence of depression among first-year university students in Japan: A preliminary study. Psychiatry and Clinical Neurosciences, 54(5), 583588.

Valas, H. (2001). Learned helplessness and psychosocial adjustment: effects of age, gender and Academic achievement. Journal of educational research, 45(1), 71-90.

Van Rooij, E. C. M., Jansen, E. P. W. A., \& van de Grift, W. J. C. M. (2017). First-year university students' academic success: the importance of academic adjustment. European Journal of Psychology of Education. doi:10.1007/s10212-0170347-8

Wang, Q., Liu, H., Ren, Z., Xiong, W., He, M., Fan, X., ... \& Zhang, X. (2020). Gender difference in the association of coping styles and social support with psychological distress among patients with end-stage renal disease. PeerJ, 8, e8713.

Wheaton, B. (2007). The twain meets: distress, disorder and the continuing conundrum of categories. an interdisciplinary journal for the social study of health, illness and medicine, 11(3), 303-319. https://doi.org/10.117711363459307 077545

Yusoff, Y. M. (2012). Self-efficacy, perceived social support, and psychological adjustment in international undergraduate students in a public higher education institution in Malaysia. Journal of
Studies in International Education, 16(4), 353-371. 